\title{
Intangible Assets, Research \& Development Intensity, and Firm Value with Firm Performance as an Intervening Variable
}

\author{
Ida Subaida ${ }^{1 *}$, Lita Permata Sari ${ }^{2}$
}

\author{
${ }^{1,2}$ Abdurachman Saleh University \\ ${ }^{*}$ Corresponding author. Email: ida subaida@unars.ac.id.
}

\begin{abstract}
The company continues to strive to increase value in order to compete with other companies. These competitive advantages can be formed by the ownership of intangible assets of the company. Intangible asset investment is very important for the company's continued growth and value. In addition to intangible assets, research and development conducted by companies can also increase the value of the company. The intensity of research \& development is the discovery of insights and knowledge of new products and processes that can meet the needs of the community. The purpose of the research is to examine the direct effect of intangible assets and the intensity of research and development on firm value and the indirect effect through financial performance. This research was conducted on all companies listed on the Indonesia Stock Exchange in 2018. The data analysis method in this study is path analysis using SPSS. The results showed that intangible assets had no effect on financial performance and firm value, the intensity of research $\&$ development had a positive effect on financial performance but had no effect on firm value, and financial performance was proven to have no effect on mediating the relationship between intangible assets and the intensity of research $\&$ development on firm value.
\end{abstract}

Keywords: Intangible assets, intensity of research \& development, firm value, financial performance

\section{INTRODUCTION}

The company continues to strive to increase value in order to compete with other companies. This competitive advantage can be formed by the ownership of the company's intangible assets. Intangible assets are the main portion of company assets and have received attention from policy makers. These assets are often the only source of sustainable competitive advantage (Shin et al, 2017). Investment in tangible assets according to Murat and Derya (2019) is very important for the sustainable growth and value of the company.

Apart from intangible assets, research and development carried out by companies can also increase firm value. According to Made and Gede (2016) the intensity of research \& development is the discovery of insights and knowledge of new products and processes that can meet people's needs. The intensity of Research \& Development can also lead to continuous competition between industries, both old and new companies. Companies need to continue to carry out research \& development if they want to stay in the industry.
Firm value is the company's ability to obtain benefits that can be felt by shareholders. If the company value is high, the welfare of shareholders is also high (Mawaty et al, 2017). Research on intangible assets, research \& development intensity, company value, and company performance has been conducted by Ferdaous and Rahman (2019), Ocak and Findik (2019), Wulandari et al (2019), Kang et al (2019), Marzkova (2019), Namryoung and Jaehon (2019), Cinintya et al (2019), and Alam et al (2020).

Ferdaous and Rahman (2019) and Marzkova (2019) conducted research on intangible assets on research performance. The results showed that intangible assets have an effect on company performance.

Research on the effect of intangible assets on firm value was conducted by Ocak and Findik (2019) and Wulandari et al (2019). The study found that the intangible assets owned by the company had a positive effect on firm value. Meanwhile, Glova and Mrazkova (2018) revealed that intangible assets have no effect on firm value. 
Research conducted by Usman et al (2019), Alam et al (2020) and Cinintya et al (2019) revealed that the intensity of research \& development has a positive effect on firm performance. Meanwhile, research results. The results of research by Kang et al (2019) on intensity of research \& development show that intensity of research $\&$ development has a negative effect on firm value. The results of this study are different from the research of Namryoung and Jaehon (2019) which revealed that the intensity of research \& development has a positive effect on firm value.

This research is a development of previous research related to intangible assets, intensity of research $\&$ development, firm value, and firm performance. The development carried out in this study is to examine the direct effect of intangible assets and the intensity of research \& development on firm value and the indirect effect through company performance. Another motivation for this research is that there is a difference in the results of previous studies. Ocak and Findik (2019) and Wulandari et al (2019) show that intangible asets owned by companies have a positive effect on firm value. Meanwhile, Glova and Mrazkova (2018) revealed that intangible assets have no effect on firm value. Kang et al (2019) showed that research \& development intensity had a negativ effect on firm value. The results of this study were different from the research of Namryoung and Jaehon (2019) which revealed that intensity of research $\&$ development had a positive effect on firm value.

Another development undertaken in this research is examining all companies listed on the Indonesia Stock Exchange. Thesis a development from previous research which only examined certain sectors. The research results are expected to represent the characteristics of all sectors listed in the Indonesia Stock Exchange. The purpose of this research is to examine the direct effect of intangible assets and the intensity of research and development on firm value and the indirect effect through company performance.

\section{LITERATURE REVIEW}

\subsection{Intangible Assets on Company Performance}

There is a link between resources and company success. Resources owned by the company allow the company to obtain high returns on the use of capital (Michael Hitt, 1999: 23 in Solihin, 2012: 59). Research conducted by Marzkova (2019) regarding intangible assets on company performance was conducted at companies listed on the West and North European Stock Exchanges in 2013-2017. Testing is done using regression analysis. The results showed that intangible assets have an effect on firm performance.

Other research related to intangible assets on firm performance was conducted by Ferdaous and Rahman (2019). The study was conducted at four industrial manufacturing companies in DSE, Bangladesh. The results of the study report that intangible assets have an effect on firm performance.

H1. Intangible Assets have a positive effect on Firm Performance

\subsection{Research \& Development Intensity on Firm Performance}

Alam et al (2020) conducted research on intangible assets on firm performance on the Data Stream, World Bank's Protecting Minority Shareholder data, and the International Country Risk Guide (ICRG) database. The results revealed that the intensity of research \& development had a positive effect on firm performance. Companies with high research \& development investment will generate higher returns as well. The company will feel more responsible when it has carried out research \& development activities that encourage the creation of high company performance.

Cinintya et al (2019) also conducted research related to intangible assets on firm performance. The research was conducted on non-financial companies listed on the Indonesia, Malaysia, Singapore, and the Philippines Stock Exchanges. The results of the study prove that the intensity of research $\&$ development has a positive effect on firm performance. Research \& development activities carried out by companies are proven to help companies to succeed in a competitive corporate environment.

H2. The Intensity of Research \& Development has a positive effect on Firm Performance

\subsection{Intangible Assets to Firm Value}

Ocak and Findik (2019) conducted research on intangible assets against firm value. The research was conducted at manufacturing companies listed on the Istanbul Stock Exchange. Tests were carried out with Ordinary Least Squares (OLS). The results showed that intangible assets have a positive effect on firm value. Companies with larger intangible assets tend to have better corporate value as well.

Wulandari et al (2019) also conducted research on intangible assets against firm value. The research test was conducted using multiple regression testing with a sample of 15 manufacturing companies listed on the Indonesia Stock Exchange. The results revealed that intangible assets have a positive effect on firm value. Intangible assets are hidden values that determine the company's success which can led to an increase in company value. Intangible assets are also a positive signal that can cause an increase in share prices.

H3. Intangible Assets have a positive effect on Firm Value 


\subsection{Intensity of Research \& Development towards Firm Value}

Research on intensity of research \& development was carried out by Namryoung and Jaehong (2019). The research was carried out on companies listed on the Korea Stock Exchange by excluding financial companies. The results of the study reported that the intensity of research \& development had a positive efect on firm value. Company investment through research \& development is responded positively by the market so that it can cause firm value to also increase.

Glova and Mrazkova (2018) conducted intensity of research \& development research on firm value in public companies in Europe. The results showed that Research \& Development had a positive effect on firm value. Investing in research \& development is one that the market evaluates as a positive signal.

H4. Research \& Development intensity has a positive effect on Firm Value

\subsection{Intangible Assets to Firm Value Mediated by Firm Performance}

Based on the resources based theory, if the company has the right resources and capabilities, then the company will have high industrial attractiveness which is reflected in the high profits generated (Solihin, 2012: 59). Investors will be attracted to companies with high industrial attractiveness data.

Competitive advantage can be achieved by the company if the company can take advantage of its resources. These resources can be intangible assets. Intangible assets owned by the company will encourage increased performance for the company which in the future can result in the creation of positive signals for investors (Prawira and Made, 2016).

H5. Firm performance has a positive effect in mediating the relationship between intangible assets and firm value.

\subsection{Intensity of Research \& Development on Firm Value mediated by Firm Performance}

Several studies related to intensity of research \& development on firm performance, namely the research of Usman et al (2019), Alam et al (2020) and Cinintya et al (2019) revealed that intensity of research \& development has a positive effect on firm performance. Research on intensity of research \& development on firm value is Namryoung and Jaehon's research (2019) which reveals that intensity of research \& development has a positive effect on firm value.
H6. Firm performance has a positive effect in mediating the relationship between Intensity of Research \& Development and Firm Value.

\section{RESEARCH METHOD}

\subsection{Research Design}

This research is a positive study with the aim of testing the hypothesis. Hypothesis testing is to test the effect of the independent variable in the form of intangible assets and intensity of research \& development on the dependent variable in the form of firm value, either directly or indirectly through the intervening variable of firm performance.

\subsection{Types and Sources of Data}

The type and source of data used in this study are secondary data, annual reports and share prices of all companies listed on the Indonesia Stock Exchange in 2018.

\subsection{Population and Sample}

The population of this study is all companies listed on the Indonesia Stock Exchange in 2018. The selection of this population is a development from previous research that only examined certain sectors. The selection of the population in this study is expected to provide results that represent the characteristics of all sectors contained in the Indonesia Stock Exchange. The sample was selected using purposive sampling, with criteria (a) providing the information needed in research during 2018, (b) not experiencing losses in the year of observation, and (c) presenting financial information in Indonesian Rupiah.

\subsection{Research Variables}

The independent variables in this study are intangible assets and the intensity of research \& development. Intangible assets in this study are measured by the difference between the market value of the company and its book value (Lev, 2001). This measurement has been used by Prawira and Made (2016). Intangible Assets can be calculated as follows:

CMV $=$ Number of Shares Outstanding $x$ End of Year Closing Share Price

BNVA $=$ Total Assets - Total Liabilities

INTAV $=\mathrm{CMV}-\mathrm{BNVA}$

$\begin{array}{lr}\text { CMV } & : \text { Corporate Market Value } \\ \text { BNV } & : \text { Book Value of Net Asset } \\ \text { INTAV } & \text { Intangible Asset Value }\end{array}$

Research \& Development intensity is measured by RDI. This measurement has been used by the research of Prawira and Made (2016). RDI can be calculated using the formula: 


\section{RDI $=($ Total R\&D Expenditure $) /$ Sales}

The independent variable of this study is firm value. Firm value in this study is measured by Tobins Q. This measurement has been used by Subaida et al (2018). Tobins Q can be calculated using the formula (Herawaty, 2008):

Tobins $\mathbf{Q}=(\mathrm{MVE}+\mathrm{D}) /(\mathrm{BVE}+\mathrm{D})$

Tobins Q : Firm Value

MVE : Equity Marker Value, which is obtained from the multiplication of the year-end closing share price with the number of shares outstanding at the end of the year

D : Book value of total debt

BVE : Equity Book Value, which is obtained from the difference between the company's total assets and total liabilities

The intervening variable of this research is firm performance. In this study, the firm performance is measured using Return on Asset (ROA). ROA was chosen as a measure of firm performance in this study because the dependent variable used in this study is intangible assets which are part of the assets owned by the company. This measurement has been used by the research of Adhiprasetya and Zulaikha (2019). ROA is calculated by the formula (Brigham and Houston, 2010: 146):

\section{ROA $=($ Net income $) /($ Total Assets $)$}

\subsection{Data Analysis Methods}

The analytical method used is path analysis using SPSS. Path analysis is a model used to analyze pathways in estimating the strength of the causal relationships depicted in the path model. Path analysis using SPSS is an amalgamation of regression models regarding the direct effect of the dependent variable on the independent variable and the indirect test regression model of the dependent variable on the independent variable through the intervening variable. The structural equation is as follows Sarjono and Julianita (2011):

$\mathrm{Y}=\rho \mathrm{YX}+\rho \mathrm{X} \varepsilon 1$

$Z=\rho Z X+\rho Z Y+\rho Z \varepsilon 2$

\section{RESULTS AND DISCUSSION}

\subsection{Results}

There are 676 companies listed on the Indonesia Stock Exchange which are the population of this study. Selecting the sample with the criteria of providing the information needed in the research during 2018, not experiencing a loss in 2018, and presenting financial information in Rupiah, so that the final sample of 34 companies used in this study was obtained. Testing using path analysis with SPSS analysis tool to determine the direct effect of intangible assets and the intensity of research \& development on firm value and the indirect effect through firm performance. The results of hypothesis testing can be seen in table 1 and table 2 .

Table 1. Regression Model I

\begin{tabular}{|c|c|c|c|c|c|}
\hline \multirow[t]{2}{*}{ Model } & \multicolumn{2}{|c|}{$\begin{array}{c}\text { Unstandardized } \\
\text { Coefficients }\end{array}$} & \multirow{2}{*}{$\begin{array}{l}\text { Standardized } \\
\text { Coefficients } \\
\text { Beta }\end{array}$} & \multirow[t]{2}{*}{$\mathrm{t}$} & \multirow[t]{2}{*}{ Sig. } \\
\hline & B & $\begin{array}{l}\text { Std. } \\
\text { Error }\end{array}$ & & & \\
\hline (Constant) & $\begin{array}{r}95137 \\
7.820\end{array}$ & $\begin{array}{r}26815 \\
07.801\end{array}$ & & -.355 & .725 \\
\hline Assets & $\begin{array}{l}2.084 \\
\text { E-018 }\end{array}$ & .000 & .008 & .067 & .947 \\
\hline $\begin{array}{l}\text { Intensity } \\
\text { of R\&D }\end{array}$ & .017 & .003 & .721 & 5.782 & .000 \\
\hline
\end{tabular}

a. Dependent Variable: Kinerja Perusahaan

Table 2. Regression Model II

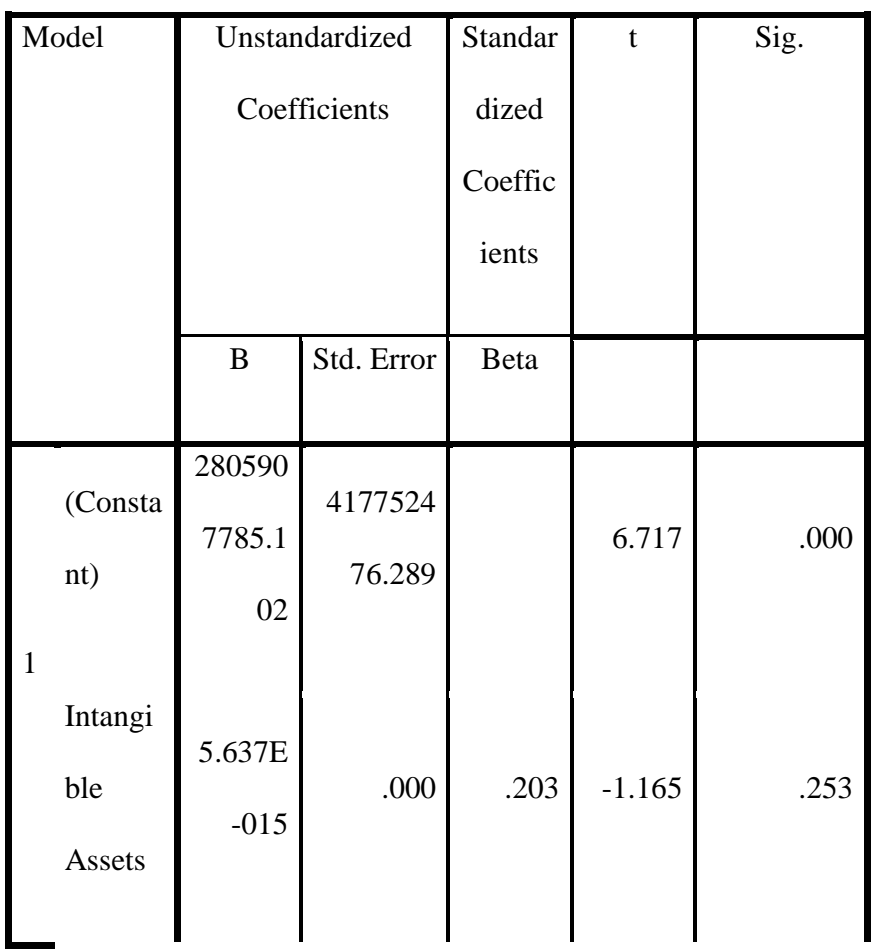




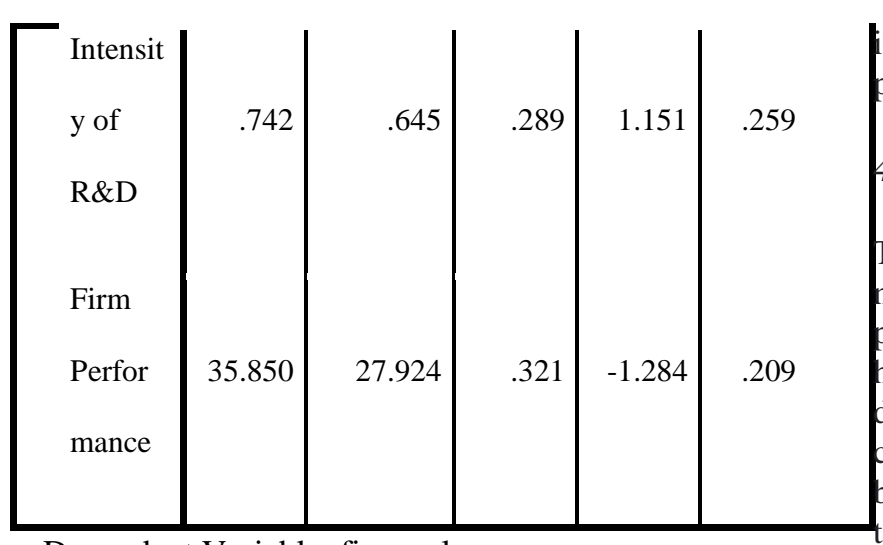

a. Dependent Variable: firm value

Hypothesis 1 of this study is that intangible assets have a positive effect on firm performance. The test results show a significance level of 0.94 . These results do not support hypothesis 1 of this study so that intangible assets have no effect on firm performance. Hypothesis 2 of this research states that the intensity of research \& development has a positive effect on firm performance. The results of statistical testing reveal that the significance level is 0.000 , which means that hypothesis 2 is supported. The intensity of research \& development has a positive effect on firm performance.

Hypothesis 3 states that intangible assets have a positive effect on firm value, the test results show a significance level of 0.253 . The level of significance is greater than 0.05 , which means that hypothesis 1 is not supported. The research results reveal that intangible assets have no effect on firm value. Hypothesis 4 of this research is that intensity of research \& development has a positive effect on firm value. The results of statistical testing show that the significance level is 0.259 . The level is greater than 0.05 which indicates that hypothesis 2 is also not supported. The results of the study proved that the intensity of research \& development had no effect on firm value.

Hypothesis 5 of this study is that firm performance has a positive effect in mediating the relationship between intangible assets and firm value. The test results show that the direct effect of intangible assets on firm value is 0.203. Meanwhile, the indirect effect of intangible assets on firm value through firm performance is $0.203 \times 0,321$ $=0.065$. The direct effect of 0.203 is greater than the indirect effect, which is 0.065 , which indicates that intangible assets through firm performance has no effect on firm value.

Hypothesis 6 states that firm performance has a positive effect in mediating the relationship between intensity of research \& development and firm value. The results of statistical testing show that the direct effect of intensity of research \& development on firm value is 0.289. Meanwhile, the indirect effect of intensity of research \& development on firm value through firm performance is $0,289 \times 0,321=0.093$. These results indicate that the ntensity of research \& development through firm performance has no effect on firm value.

\subsection{Discussion}

The first test of this research is testing hypothesis 1 , namely the effect of intangible assets on firm performance. The test results show that intangible assets have no effect on firm performance. These results can be due to as explained by Widhiastuti (2016), namely companies in Indonesia tend to still use conventional basic in managing their companies, so that the use of echnology has not been maximized. Intangible assets owned by the company have not directly influenced the company's efforts to improve firm performance.

The second test is to test the influence of intensity of research \& development on firm performance. The results of this study support the research results of Usman et al (2019), Cinintya et al (2019) and Alam et al (2020). Research \& development activities carried out by the company can result in the development of the company's products and better production process systems. Research \& development activities can also lead to the creation of more effective sales innovation (Padgett and Galan, 2010). So that companies that have high research \& development intensity can get more benefits.

The results of the research on hypothesis 3, namely intangible assets have no effect on firm value. These results support the research of Glova and Mrazkova (2018). The market does not actively evaluate the intangible assets strategy of the company. Intangible assets owned by a company are not always evaluated by the market.

Hypothesis testing 4 is testing the effect of intensity of research \& development on firm value. The test results show that the intensity of research \& development has no efect on firm value. In some conditions, investment in research \& development does not always contribute to increasing the firm value (Glova and Mrazkova, 2018). The small number of companies that disclose research $\&$ development costs in financial reports and even do not spend research \& development costs can also affect the results of testing this hypothesis. Of the 676 companies listed on the Indonesia Stock Exchange which were the population of this study, only 34 companies disclosed research \& development costs in their financial statements and met the criteria to be selected as the sample of this study.

The results of testing hypothesis 5 of this study are intangible assets through firm performance has no effect on firm value. Firm performance has a positive effect in mediating the relationship between intangible assets and firm value. The results of the study support the research conducted by Prawira and Made (2016) that firm performance does not mediate the effect of intangible assets on firm value. Investors assess the company by 
looking at the value of its intangible assets without paying attention to the increase in firm performance obtained from the utilization of these intangible assets.

The final test in this study is to test the indirect effect of intensity of research \& development on firm value through firm performance. The test results show that the intensity of research \& development through firm performance has no effect on firm value. The results of hypothesis 6 testing also support the results of research conducted by Prawira and Made (2016), namely that there is no influence of intensity of research \& development on firm value through firm performance. Investors also do not catch the signal of high firm performance due to the high intensity of research $\&$ development, but investors may be able to give an assessment to the company of the high intensity of research \& development being carried out. The number of companies that do not disclose research \& development costs and even research \& development costs can also affect the results of this study.

\section{CONCLUSIONS}

The results showed that intangible assets had no effect on firm performance and firm value, intensity of research \& development had a positive effect on firm performance but had no effect on firm value, and firm performance proved to have no effect in mediating the relationship between intangible assets and intensity of research \& development on firm value. The results of the research have implications, namely that they can be used as input in making company decisions related to improving firm performance by paying more attention to the intensity of research \& development. Research and development activities of the company need to be understood that this is important for the company's attention in order to achieve an increase in firm performance. Companies need to increase awareness in the implementation of research \& development activities and disclose them in the company's financial statements.

\section{REFERENCES}

[1] Adhiprasetya, A., \& Zulaikha.. Pengaruh Corporate Governance Perception Index terhadap Nilai Perusahaan dan Kinerja Keuangan Perusahaan. Dipenegoro Journal of Accpunting, 2019, 8 (4):110.

[2] Alam, A., Uddin, M., Yazdifar, H., Shafique, S., \& Lartey, T. R\&D Investment, Firm Performance and Moderating Role of System and Safeguard: Evidence from Emerging Markets. Journal of Business Reseach, 2020, 106: 94-105.

[3] Brigham, F. Eugene dan Houston, F. Joel. Dasardasar manajemen keuangan, Buku 1. Edisi 11, 2010, Salemba Empat: Jakarta.
[4] Cinintya, P.B., Wibowo, H., \& Nurul, M.I. Intellectual Capital and Firm Performance in ASEAN: The Role of Research and Development. Journal of accounting and Investment, 2019., 20 (3).

[5] Ferdaous, J \& Rahman, M. The Effects of Intangible Assets on firm Performance: An Empirical Investigation on Selective Listed Manufacturing Firms in DSE, Bangladesh. American Journal of Business, 2019, 34 (3/4): 148-168.

[6] Glova, J., dan Mrazkova, S., Impact of Intagibles on Firm Value: An Empirical Evidence from European Public Companies. Ekonomicky Casopis, 2018, 66 (7): 665-680.

[7] Herawaty, Vinolla. Peran praktek corporate governance sebagai moderating variable dari pengaruh earnings management terhadap nilai perusahaan. 2008.

[8] Kang, M., Kim, S., \& Cho, M. The Effect of R\&D and the Control-Ownership Wedge of Firm Value: Evidence from Korean Chaebol Firms. Sustainability, 2019, 11: 1-20.

[9] Lev, B. Intangibles: Management, Measurerement, and Reporting. Washington DC. Brookings Institution Press. 2001.

[10] Made, N.A.S \& Gede, D.W. Pengaruh Ukuran Perusahaan, Tipe Industri dan Intensitas Research and Development pada Pengungkapan Modal Intellectual. 2016.

[11] Mawaty, Rufiad, E, Hardiningsih, P, \& Srimindarti, C. Corporate Governance Memoderasi Earnings Management dan Profitabilitas terhadap Nilai Perusahaan. 2017.

[12] Marzkova, S. Intangible Assets and Firm Performance: Evidence from Western and Northern Europe. European Conference on Intangibles and Intellectual Capital, 2019, 193-201.

[13] Namryoung, L. \& Jaehong, L. External Financing, R\&D Intensity, and Firm Value in Biotechnology Companies. Sustainibility, 2019, 11: 1-18.

[14] Ocak, Murat \& Findik, Derya. The Impact of Intangible Assets and Sub-Components of Intangible Assets on Sustainable Growth and Firm Value: Evidence from Turkish Listed Firms. MDPI, 2019, 1-23.

[15] Padgett, R.C \& Galan, J.I. The Effect of R\&D Intensuty on Corporate Social Responsibility. Journal of Business Ethics, 2010, 93 (3): 407-418.

[16] Prawira, K.A., \& Made, I.M. Kinerja Keuangan Sebagai Pemediasi Pengaruh Intensitas Research Dan Development Dan Aset Tidak Berwujud Pada 
Nilai Perusahaan. E-Jurnal Akuntansi Universitas Udayana, 2016, 14 (1): 723-750.

[17] Sarjono, Haryadi dan Julianita Winda. SPSS vs LISREL: sebuah pengantar, aplikasi untuk riset, 2011. Salemba Empat: Jakarta.

[18] Shin, N., Kraemer, K.L., \& Dedrick, J. R\&D and Firm Performance in the Semiconductor Industry. Industry and Innovation, 2017, 24 (3): 280-297.

[19] Solihin, Ismail. Manajemen strategik, Erlangga: Jakarta. 2012.

[20] Subaida, I., Nurkholis, \& Mardiati, E. Effect of Intellectual Capital and Intellectual Capital Disclosure on Firm Value. Jurnal of Applied Management (JAM), 2018, 16 (1):125-135.

[21] Sung, K.W., Kunsu, P., Hoon, L.S., \& Hongyoung, K. R\&D Investments and Firm Value: Evidence from China. Sustainability, 2018, 10: 1-17.

[22] Usman, Y.M., Kashif, K.M., Ahmed, A., \& Zulfiqar, M. Empirical Investigation of Relationship Between Research and Development Intensity and Firm Performance: The Role of Ownership Structure and Board Structure. International Journal of Financial Engineering, 2019, 6 (2).

[23] Widhiastuti, S. Peran Mediasi Kinerja Keuangan terhadapHubungan antara Aset Tidak Berwujud terhadap Kinerja Pasar. Media Riset Akuntansi, Auditing, \& Informasi, 2016, 16 (1):15-38.

[24] Wulandari, E., Rinofah R., \& Mujino, M. Pengaruh Intangible Aset, Debt to Equity Ratio, dan Return on Asset terhadap Nilai Perusahaan Manufaktur yang terdaftar di Bursa Efek Indonesia Periode 20142018. Journal of Management and Business, 2019, 2 (2): 86-96. 